\title{
STRIKE OUTCOMES AND WAGE SETTLEMENTS IN SPAIN
}

\author{
Sergi Jimenez-Martin ${ }^{\aleph}$ \\ Universitat Pompeu Fabra
}

\begin{abstract}
This paper analyzes collective bargaining using Spanish firm level data. Central to the analysis are the joint determination of wage and strike outcomes in a dynamic framework and the possibility of segregate wage equation for strike and non-strike outcomes. Conditional to strikes taking place, we confirm a negative relationship between strike duration and wage changes in a dynamic context. Furthermore, we find selection in wage equations induced by the strike outcome. In this sense, the possibility of wage determination processes being different in strike and non-strike samples is not rejected by the data. In particular, wage dynamics are of opposite sing in both strike and non-strike equations. Finally, we find evidence of a 0.33 percentage points wage change strike premium.
\end{abstract}

JEL CODE: J52-C33-C35

KEYWORDS: WAGE SETTING, STRIKE, COLLECTIVE BARGAINING, PANEL DATA, SELECTION.

`Department of Economics. Ramon Trias Fargas 25-27. Phone: +3493 5421667. e-mail: sergi.jimenez@upf.edu. I am very grateful to José María Labeaga and Samuel Gil for helpful comments. We would also like to thank the Dirección General de Política Económica for providing data. Financial help from BEC2002-04294-C02 is gratefully acknowledged. 


\section{Introduction.}

The literature on the relationship between strike and wage outcomes has two strands. The first strand argues that strikes are accidents, or mistakes, that occur during bargaining (Siebert and Addison (1981)). The second strand, inspired on the seminal work of Hicks (1932), stresses a negative relationship or concession schedule between the length of a strike and wage settlement. ${ }^{1}$ On very rare ocassions the possibility of different wage-strike regimes has been called into question, though. Among the few exceptions we can mention, from a theoretical point of view, Cramton and Tracy's (1994, 2003) wage bargaining model with time varying threats; and, from the empirical point of view, Stengos and Swidinsky (1990) who find empirical evidence of small strikers' wage premium in Canada.

The empirical literature using microeconomic data has found ambiguous results regarding the slope of the concession schedule. In fact, Canada and the US are the only countries where a considerable amount of applied work has been done on microdata. As for Canada, in a single equation context, Ridell (1980) and Lacroix (1986) find that strikes imply significantly higher wage changes, even though such a finding does not survive to an unrestricted treatment of the annual effects in the wage equation. Using panel data and controlling for bargaining pairs heterogeneity (by first differencing the data in a pseudo dynamic context), Card (1990b) finds virtually no relationship between strike duration and expected wages. In a two-equation framework, Stengos and Swindinsky (1990) find evidence both of selection induced by the strike outcome and a (small) wage premium for strikers. Good examples using US data are Vroman (1984) and McConnell (1989). Whereas Vroman finds no relationship between strike duration and wages, McConnell (1989) finds a negative relationship between strike duration and the unpredictable component of the wage.

In Europe, research has focused on strike determination. For example, van Ours and van de Wijngaert (1996) analyze a combined wage and holdout model using industry data from The Netherlands. More recently, Jiménez-Martín (1999) using Spanish data detects, in a static context, a significant negative relationship between strike and wage outcomes, after controlling for unobserved heterogeneity and endogeneity.

It is thus clear that in this set of empirical studies there is very contradictory evidence on the slope of the wage concession curve as well as on the implicit wage premium (or cost) from a strike. Furthermore, it is still unclear the dynamic nature of the wage process, ${ }^{2}$ or, more importantly, whether one or two-wage 
equations should be specified. Our work combines a careful treatment of the endogeneity of dispute variables in dynamic wage settlement equations in a panel data context with a room open to segregate wage equations for each strike regime. $^{3}$

We use data from the Spanish Survey of Collective Bargaining in Large Firms (CBLFS). It provides data on initial bargaining offers, negotiation timing, strike activity, wage changes, and other variables on a yearly basis (see the data Appendix). As regards to estimation procedures, we use the Arellano and Bond (1991) general method of moment instrumental variables (GMM-IV) estimator. A Wald test comparing the estimates of each equation helps explain any difference in the behavior of firms for each strike regime. Furthermore, a test of selection (Wooldrigde, 1995) in any of the two wage equations may shed some light to the endogeneity issue.

We obtain four main findings. First, we confirm the negative slope of the wage concession schedule in the case of the Spanish data, as in Jiménez-Martín (1999). Second, the hypothesis that the strike and nonstrike equations differ cannot be rejected. Third, we detect significant wage dynamics in the non-strike equation, missing it in the pooled (strike and non-strike observations) equation. And, finally, (a result that should be taken cautiously) we find that strikers get a significant wage increase premium. Perhaps not surprisingly, the wage premium for strikers is similar to that obtained by Stengos and Swidinsky (1990).

The rest of the paper is organized as follows. In section II, the Spanish negotiation framework is briefly outlined. The empirical framework, the econometric and testing methods used in this paper are presented in section III. Empirical findings and the sequence of tests conducted are discussed in section IV, while section V summarizes the above.

\section{Spanish negotiation framework.}

Bargaining procedures in Spain, like in other European countries, differs sharply from those in North America. ${ }^{4}$ Negotiations take place simultaneously at the national, industry, and firm levels. The influence of nationwide unions (despite a low level of affiliation ${ }^{5}$ ) is strong because they carry out negotiations at the national or industry-wide levels. Elected work councils substitute for unions at firm-level negotiations and can call for a strike, which is a major difference with other European countries. During the sample period, 
the coverage of the Spanish Collective Bargaining system is notably high. From 1984 to 1991 almost 82 per cent of all employees were covered by Collective Bargaining agreements, of which 20 per cent were signed under a firm-level basis. The terms of industry level agreements set a binding floor for all the firms in the sector due to the mandatory extension principle that is common across Europe. This configuration leads to an inflationary bias because firms which are doing well can pay higher wages while firms which are not doing so well are prevented from paying lower wages (Blanchard et al., 1995).

Current working and pay conditions are settled in a "convenio colectivo", a protocol that stipulates wages, hours and other working conditions over a given number of years (around 70 per cent of them are valid for a year and 25.2 for two years). However, the wage changes and hours of multiyear agreements are normally renegotiated every year ( 88 per cent of the agreements have economic effects over a single year and 9.4 per cent over 18 months). The influence of the annual national or industry-level bargaining explains why the length of the contract still has limited importance in the case of Spain.

The flow of information between negotiation units is large because agreements must be registered to acquire full validity and agents are vertically organized across negotiation units. In fact, firm-level units should use this information to fix their own wage changes because it simultaneously captures the effect of inflation and the alternative wage. ${ }^{6}$

\section{The empirical framework, the econometric and testing methods.}

\section{a. A framework for the analysis.}

A vast majority of the recent models postulate that the duration of the negotiation threats (either the length of a strike, the holdout period or even a mixed threat) is determined by the time needed to credibly establish that the employer's demand price for labor is no higher than the true one. Then, the wage settlement splits the difference between the demand and supply prices. Card (1990b), Cramton and Tracy (1992, 1994) and Cramton, Gunderson and Tracy (1999) provide recent examples in a non-dynamic context. $^{7}$ All of them agree on the idea that longer strikes would, in general, produce lower observed wages.

In our benchmark equation (see Kennan and Wilson, 1989), the wage change settlement ( $\dot{w})$ depends linearly on strike variables $(s, d)$, observed variables $(X)$ and an unobserved component. The unobserved 
part has two components. The first component or bargaining pair heterogeneity effect $(\mu)$ randomly varies across observations. The second component $(e)$ shifts firm valuation. Summarizing,

$$
\dot{w}_{i}=\delta_{1} s_{i}+\delta_{2} d_{i}+X_{i}^{\prime} \gamma+\mu_{i}+e_{i}
$$

where $s$ takes the value one if a strike is observed and zero otherwise, and $d$ is the realized length of a work stoppage, which is jointly determined with the wage settlement. Note that $\dot{w}(d=0)$ can be thought of as the maximum wage change available for workers, i.e., a corner solution for the strike wages. Furthermore, from standard strike theory (Hicks, 1932) it is expected that $\delta_{2}<0$.

In a single equation context, the empirical evidence using panel data is puzzling. While Card (1990b) finds no systematic relationship between wage outcomes and strike variables, the evidence found by McConnell (1989) is just the opposite. In both cases a control for bargaining pairs heterogeneity is introduced, but the strike variables are treated as strictly exogenous. Jiménez-Martín (1999) shows that it is not only necessary to control for unobserved heterogeneity but also for endogeneity. When those problems are controlled for, a strong negative correlation between the strike duration and the wage is evidenced.

In the present work we extend the previous setup to a two-equation framework, one for each strike regime: ${ }^{8}$

$$
\begin{array}{ll}
\dot{w}_{i}^{0}=X_{i}^{\prime} \gamma^{0}+\mu_{i}^{0}+e_{i}^{0} & \text { if } s_{i}=0 \\
\dot{w}_{i}^{1}=\delta_{2}^{1} d_{i}+X_{i}^{\prime} \gamma^{1}+\mu_{i}^{1}+e_{i}^{1} & \text { if } s_{i}=1
\end{array}
$$

Thus, the strike indicator, $s_{i}\left(1\left(s_{i}^{*}>0\right)\right)$, determines whether the strike wage $\left(\dot{w}_{i}^{l}\right)$ or the non-strike wage $\left(\dot{w}_{i}^{O}\right)$ is observed. In this context, Stengos and Swidinsky (1990) find evidence of selection induced by the strike indicator, and behavioral differences between both strike regimes. However they neither consider (because of data limitations) the effect of the strike duration in the strike wage equation nor exploit the dynamic nature of the negotiation process.

\section{b. Econometric specification and methods.}

A large and increasing number of literature analyze wages in a dynamic setup because of two 
reasons. ${ }^{10}$ First, a single negotiation is embedded in a lengthy negotiation process. And second, in most cases the terms and conditions of the previous contract hold during the negotiation period, as noted by Cramton and Tracy $(1992,1994,2003)$. Consequently, current negotiation cannot be isolated from past (or future) annual negotiation or renegotiations rounds. Thus, a dynamic model corresponding to (2.0)-(2.1) in a panel framework can be specified as:

$$
\begin{array}{lll}
\dot{w}_{i t}^{0}=\alpha^{0} \dot{w}_{i t-1}^{0}+X_{i t}^{\prime} \gamma^{0}+\mu_{i}^{0}+e_{i t}^{0} & \text { if } s_{i t}=0 ; & \text { for } t_{i}^{0} \text { s.t. } s_{i t}=0 ; i=1, \ldots, N \\
\dot{w}_{i t}^{l}=\alpha^{1} \dot{w}_{i t-1}^{l}+\delta_{2}^{l} d_{i t}+X_{i t}^{\prime} \gamma^{1}+\mu_{i}^{1}+e_{i t}^{l} & \text { if } s_{i t}=1 ; & \text { for } t_{i}^{1} \text { s.t. } s_{i t}=1 ; i=1, \ldots, N
\end{array}
$$

Where $t_{i}^{j}$ denotes all the observations for which $s=j ; j=0,1$. We should take into account that, in general, neither $E\left(e_{i t}^{0} / s_{i t}^{*} \leq 0\right)$ or $E\left(e_{i t}^{l} / s_{i t}^{*}>0\right)$ is expected to be zero. Assumingthat the errors in (3.0)-(3.1) are jointly normal, we estimate a (reduced form) model for the strike decision and then we correct the wage equations with the corresponding inverse Mill's ratio. Adding consistent estimates of the inverse Mill's ratio, ${ }^{11}$ say $\hat{\lambda}_{i}^{0}$ and $\hat{\lambda}_{i}^{l}$, to (6.0) and (6.1), respectively, we obtain:

$$
\begin{aligned}
& \dot{w}_{i t}^{0}=\alpha{ }^{0} \dot{w}_{i t-1}^{0}+X_{i t}^{\prime} \gamma^{0}+\sigma_{0} \hat{\lambda}_{i t}^{0}+\mu_{i}^{0}+e_{i t}^{* 0} \quad \text { if } s_{i t}=0 \quad \text { for } t_{i}^{0} \text { s.t. } s_{i t}=0 \\
& \dot{w}_{i t}^{l}=\alpha^{1} \dot{w}_{i t-1}^{1}+\delta_{2}^{l} d_{i t}+X_{i t}^{1} \gamma^{1}+\sigma_{1} \hat{\lambda}_{i t}^{l}+\mu_{i}^{l}+e_{i t}^{* 1} \quad \text { if } s_{i t}=1 \quad \text { for } t_{i}^{1} \text { s.t. } s_{i t}=1
\end{aligned}
$$

Note thatat least the lagged dependents are correlated with the correspondent heterogeneity effects. Moreover, there are other variables (e.g. the strike outcomes in 3.1) potentially correlated with both $\mu_{i}$ and $e_{i t}$. In a static single equation context, Jiménez-Martín (1999) finds a strong correlation between the bargaining union (BU) effects and the explanatory variables. Consequently, an instrumental variable method to the first-differenced version of (4.0) and (4.1) is strongly recommended.

$$
\begin{array}{lll}
\Delta \dot{w}_{i t}^{0}=\alpha^{0} \Delta \dot{w}_{i t-1}^{0}+\Delta X_{i t}^{\prime} \gamma^{0}+\sigma_{0} \Delta \hat{\lambda}_{i t}^{0}+\Delta e_{i t}^{* 0} & \text { if } s_{i t}=0 & \text { for } t_{i}^{0} \text { s.t. } s_{i t}, s_{i t-1}=0 \\
\Delta \dot{w}_{i t}^{1}=\alpha^{1} \Delta \dot{w}_{i t-1}^{1}+\delta_{2}^{1} \Delta d_{i t}+\Delta X_{i t}^{\prime} \gamma^{1}+\sigma_{1} \Delta \hat{\lambda}_{i t}^{1}+\Delta e_{i t}^{* 1} & \text { if } s_{i t}=1 & \text { for } t_{i}^{1} \text { s.t. } s_{i t}, s_{i t-1}=1
\end{array}
$$

Notice the changes in the sampling rule under both regimes. Provided $n$ is large and $T$ fixed, we consistently estimate these equations using Arellano and Bond's (1991) GMM-IV estimator. Under the assumption that the error term in (3.j) is serially uncorrelated, all variables dated $t-2$ and before are, in 
principle, valid instruments for (5.j). ${ }^{12}$ Notice that in the latter case, the relevant samples are constructed by picking up at least two strike outcomes (strike wage sample) or two non-strike outcomes (non-strike wage sample). Unfortunately, after selecting the observations in this way, the strike sample used in this study is not large enough to allowing the identification of the relevant parameters of the strike wage equation using a first differences method

In the testing procedures, we compare (when feasible) the estimates of the strike and non-strike wage equations excluding the intercept and strike variables using a Wald test to account for the possibility of different structural parameters. In addition, we perform a variable addition test for selection bias. The procedure, following Wooldridge (1995), may be stated as follows. First, we estimate $T$ decision equations using standard discrete choice models. Then, we compute the inverse Mill's ratio for each observation in each time period. In a second stage, we estimate either levels (4.j) or first-differenced equations (5.j) by instrumental variables and test the null hypothesis that the coefficient of the selection term is zero. The test is conducted both in the level and in the first-differenced equations, to control for the possibility of correlated effects,. However, given the small sample size of the strike sample, first-differenced estimates are only obtainable using the non-strike sample. However, the test for selection is still valid since selection, if present, can be detected in either the strike or the non-strike sample. Finally, the comparison of the first differences estimates obtained from (5.0) and a pooled sample (strike and non-strike observations) is enough to assess the single equation against the two-equation framework.

\section{Specification and empirical results.}

\section{a. Data and variables.}

The row data from the CBLFS covers a time span of 6 years, from 1985 to 1990 . From these data we select those observations that contain information about the claim, offer, agreement, and the length of the negotiation process. It is necessary to follow these selection criteria in order to be able to use some controls concerning price expectations and wage signals. In what follows we briefly describe the set of variables employed in the analysis, which is an adaptation of that employed in Jiménez-Martín (1999). All the variables them are defined and summarized in the data Appendix. 
The first group of variables proxies the change in firm's demand price for labor. The change in the value added per employee represents the change in the level of productivity and, to some extent, in the firm's demand. Since it is fully known after the time of the contract, it must be treated as endogenous to the analysis. We include the lagged profits per employee in order to control not only the change but also the level of profitability. Both variables are expected to add upward pressure on settlements. As a major difference with regard to other studies, we use the difference between the union's initial claim and firm's initial offer during the negotiation process. This difference measures the size of the pie the parties are bargaining over and constitutes a reasonable proxy for the level of uncertainty that agents have at the beginning of the negotiation process. In addition, we include the percentage of sales in the domestic market as an indirect measure of competitive pressure. Finally, we use the shares of capital owned by foreigners, by the public sector, and by domestic shareholders, respectively, in order to account for differences in the firm's bargaining power.

With the second group of variables we try to control any difference among work councils (and hence bargaining power), as well as the characteristics of the bargaining unit, its payroll structure and the timing of negotiations. We account for the differences between work councils by including the fraction of the council members that: belong to the nationwide union Workers Commissions (CCOO), any regional union and those not belonging to any union. We complement the latter group of variables by introducing a dummy that accounts for the presence of a single union in the work council. A single union has no coordination problems and, as a result, may have greater negotiating power. In order to capture the effect of the timing for the negotiations, we introduce a dummy which takes the value one if the negotiation process starts after the expiration of the former contract. As usual, the bargaining unit status quo and size can be represented by the lagged relative wage and by the lagged level of employment, respectively. We also control for the existence of a cost of living allowance clause, which is expected to lower non-contingent settlements.

Finally, we control for the incidence of market conditions. The level of industry conflicting activity proxies the aggregate bargaining pressure and offers an excellent source of instruments. Either an increase in the regional unemployment rate, or a fall in the rate of change of industry employment, produces a drop in the alternative wage. Consequently, they should reduce settlements. The higher the expected price level, the 
higher the settlement expected. Moreover, the industry average settlement (in the month preceding the signing) stands for the information that agents have about other bargaining unit actions and it could capture the wage spillover (McConnell, 1989). Finally, we also consider a set of calendar (year and seasonal) and industry dummies.

\section{b. On the specification and testing results.}

The results of estimating the wage change equations are reported in Table 1. We have performed a formal test for the absence of heterogeneous effects, which has been rejected in columns 2 and $5 .{ }^{13}$ Thus, there is sound evidence against the validity of level estimates. As for the estimates obtained from the differenced equations, they completely pass the standard specification test. We find first order serial correlation as well as the absence of second order serial correlation. Jointly, they both imply that the error in levels is white noise (Arellano and Bond, 1991). Finally, the test for over-identifying restrictions shows the adequacy of the set of instruments used.

\section{[Table 1 here]}

The evidence on the decline of wage settlements in a single equation dynamic context ${ }^{14}$ is grossly consistent with Jimenez-Martin (1999) and opposite to what was found in Card (1990b). Thus, there is sound evidence in favor of a downward sloping wage-concession schedule. However, note that the joint effect of the strike variables is positive for short strikes and negative for long ones (above 20 days). Furthermore, the decline is, in terms of wage levels, rather small. The estimated range for a one-month strike is 0.1 to 0.3 per cent. In a previous study for the US, McConnell (1989) found a wage level decline of 3.0 per cent after a 100-day conflict, which is slightly above the upper bound of our preferred estimate for a 100-day strike, 2.28 per cent. Note, however, that a 100-day strike is rarely observed (less than two per cent of the cases) in our sample.

Note that in a single equation context no significant dynamic effect remains, ${ }^{15}$ whereas a significant negative effect of the lagged dependent is found when the sample is restricted to non-strike observations. This is the consequence of the fact that the coefficients of the lagged dependent are of different sign in both the strike (positive and, thus, more inertia) and non-strike equations (negative and, thus, less inertia). 
In the rest of Table 1 we report the estimates obtained by considering the possibility of two different wage equations, one for each strike regime. Column 3 and 4 report level estimates of the strike and nonstrike wage change equations, respectively. A Wald test rejects the null hypothesis of equal coefficients (excluding those of the strike variables) between these two equations. In fact, relevant differences in the key coefficients can easily be detected. However, we must be cautious because of level estimates are likely to be inconsistent. Using the non-strike sample, a formal test for the nonexistence of bargaining pair heterogeneity effects is rejected, invalidating the non-strike level estimates (that is those reported in column 4). Consequently, fully consistent estimates are only obtainable using the non-strike sample (see column 5). In addition, we reject the null of equal coefficients between those obtained using the overall sample and those obtained using non-strike observations. Finally, the variable addition test on the augmented model using the Mill's ratio rejects the null of the absence of sample selection bias. ${ }^{16}$

\section{c. The economic interpretation of the results.}

We confirm the relevance of the difference between the initial claim and offer (a proxy of the level of uncertainty during negotiations), which is translated to a greater extent into wage changes for the non-strike sample. In other words, it implies greater concession rates on behalf of the strikers, so that, strikers are able to capture a smaller share of the pie in dispute.

With regard to the firm variables, both the level and the dummy of positive lagged profits have a positive coefficient, as is expected in the context of OSAI models. Thus, firms with higher profits tend to grant workers a relatively higher wage change. However, contradictory results are obtained as regards the change in the value added per employee. Although it is positive and significant in column (1), it is particularly disappointing when the wrong sign is revealed in the case of non-strike differenced estimates (column (5)).

We find a non-significant indication that exporting firms suffer a stronger wage change pressure since the greater the proportion of sales in the internal market, the lower the settlement. Furthermore, publicowned firms pay a wage change premium with respect to foreign-owned firms. However, the coefficient is non-significant in the non-strike first-difference equation (column (5)). This may be due to the fact that public-owned firms during the eighties, in addition to having very powerful unions, did not have to worry 
much about performance and competitiveness, due to the existence of strong subsidies.

There is also a significant negative association between the settlement and the proportion of regional representatives in the work council. The concession of a cost of living allowance clause, significant in most columns, decreases the settlement. The size of the bargaining unit seems to reduce the settlement in the case of the non-strike sample. This is due to the fact that larger negotiation units are able to diversify negotiation issues (for example, by considering bonuses and/or productivity payments).

The aggregate and industry indicators show contradictory results. While price and conflicting variables show in general significant coefficients, the effect of both the unemployment and employment variables are insignificant. As in Card (1990b), the conflicting activity variable is positively correlated with settlements, providing evidence of a spillover effect. The industry average wage change and the expected inflation level strongly influence the agreement. Note that the expected inflation level is more significant for strikers than it is for non-strikers. This reflects the fact that strikers try to index their settlement to the level of inflation, illustrating how the current system of wage bargaining results in an inflationary bias. ${ }^{17}$

\section{d. Strike/non-strike wage differential.}

The results obtained allow us also to draw some conclusions about the implicit wage change differential between both strike regimes (see Table 1). The differential is computed ${ }^{18}$ by using the level estimates obtained restricting the sample to strike (Table 1(3)) and non-strike (Table 1(4)) observations. As above mentioned, level estimates have been found to be inconsistent. Thus, the wage change differential is only computed for illustrative purposes.

\section{[Table 2 here]}

Our sample mean corrected differential is 0.33 percentage points. The uncorrected estimate is roughly the same, because of the small effect of selection terms. Surprisingly, our result is almost identical to that obtained by Stengos and Swidinsky (1990) using Canadian data, 0.36. By sector, the largest differences appear in the Minerals and Chemical industry and in Retail Services, whereas the lowest drifts appear in the Energy and Utilities industry. Finally, note that the differential sharply decreases according to the length of a work stoppage. In this respect after a fortnight strike, it falls by two thirds; after a month, the premia turns 
negative; and, finally, after a hundred years strike it turns very negative.

\section{[Table 3 here]}

\section{Conclusions.}

This study focuses on the analysis of the empirical relationship between wage settlements and strike outcomes using a unique Spanish data set. The analysis addresses the possibilities of different determination processes for strike and non-strike outcomes, the need for a careful statistical treatment of endogeneity of strike variables and dynamics in wage settlement equations.

On regards to specification results we, firstly, have rejected, both in a single and a two-equation context, the hypothesis of absence of unobserved bargaining unit heterogeneity, which in turn it is removed by first differencing the equations Secondly, two pieces of evidence undermine the assumption of exogeneity of strike outcomes in wage equations. On the one hand, in a single equation context, as in Jiménez-Martín (1999), we reject the strict exogeneity assumption. On the other hand, in a two-equation context, we find evidence of self-selection. Thirdly, in a single equation context, the effect of the lagged dependent is not significant, whereas it shows a significant negative effect when the sample is restricted to non-strike observations. This is likely to be due to the fact that the coefficients of the lagged dependent have opposite signs in the strike and non-strike equations. Finally and more importantly, we reject the existence of a unique wage regime. So as we cannot reject the existence of two distinct wage determination processes: strike and non-strike. Note that the latter result does not simplify the empirical work since the strike wage change equation cannot be properly identified, because the small sample size of our data set. In a sense, ours is a very negative result.

On regards to economic results we, first, confirm the negative slope of the wage concession schedule in Spanish case. Second, in all cases we find that the estimates of the wage change equation suggests that uncertainty and profitability measures are important determinants of the settlement. Of particular significance are the effect of the difference between the initials claim and offer, which acts as a proxy of level of uncertainty, and the effect the industry average wage change. The latter has a greater influence than other market factors, suggesting that some sort of wage rigidity exists in Spain. And finally, we find that strikers get a significant wage increase premium ( 0.33 basis percentage points) that decreases with the 
length of the work stoppage. Surprisingly, the wage premium for strikers is similar to that obtained by Stengos and Swidinsky (1990). As a final remark just remind that, since the strike equation is not properly identified, the latter result should be taken with caution. 


\section{References.}

Arellano, Manuel "On the Testing of Correlated Effects with Panel Data," Journal of Econometrics, 59 (1993): 87-97. and Bond, Steve "Some Tests of Specification for Panel Data: Monte Carlo Evidence and an Application to Employment Equations," Review of Economic Studies, 58 (1991): 277-297.

Ashenfelter, Orley and Johnson, George E. "Bargaining Theory, Trade Unions and Industrial Strike Activity," American Economic Review, 59 (1969): 39-49.

Blanchard, Olivier and Jimeno, Juan F. (coor.) et al. Spanish Unemployment: Is There a Solution? CEPR Report, London, 1995.

Blanchard, O. and Katz, L.F. (1999) "Wage Dynamics: Reconciling Theory and Evidence”, American Economic Review, Papers and Proceedings, 89, 69-74

Card, David "Strikes and Bargaining: A Survey of the Recent Empirical Literature," American Economic Review (AEA papers and proceedings) 80 (1990a): 410-415.

"Strikes and Wages: A Test of an Asymmetric Information Model," Quarterly Journal of Economics, 105 (1990b): 625-659.

Cramton, Peter, Gunderson and Tracy, John "The effect of Collective Barganing Legislation on Strikes and Wages, Review of Economics and Statistics, 1999, 81(3), 475-487.

Cramton, Peter and Tracy, John "Strikes and Holdouts in Wage Bargaining: Theory and Data," American Economic Review, 82 (1992): 100-121. and "Wage Bargaining with Time-varying Threats" Journal of Labor Economics, 12 (1994): 594-617. and "Unions, Bargaining and Strikes" in J.T. Addison and C. Schnabel (eds.)) International Handbook of Trade Unions, Cheltenham, UK: Edward Elgar, Chapter 4, 2003, forthcoming.

Griliches, Zvi and Hausman, Jerry A. "Errors in Variables in Panel Data," Journal of Econometrics, 31 (1986): 93-118.

Hayes, Beth "Unions and Strikes with Asymmetric Information," Journal of Labor Economics, 2 (1984): $57-$ 83.

Heckman, James J. "The Common Structure of Statistical Models of Truncation, Sample Selection and Limited Dependent Variables as a Simple Estimator for such Models," Annals of Economic and Social Measurement, 5 (1976): 475-92.

Hicks, John R. The Theory of Strikes, London: MacMillan Press, 1932.

Holtz-Eakin, David "Testing for Individuals Effects in Autoregressive Models," Journal of Econometrics, 39 (1988): 297-307.

Jimenez-Martin, Sergi "The incidence, Duration and the Wage change Effect of a Strike: Evidence from the Spanish NCGE survey," D.T. 113/1995, Madrid, FIES, 1995. 
Jimenez-Martin, Sergi "On the Testing of Heterogeneity Effects in Dynamic Panel Data Models ", Economic Letters, 58, 157-163, 1998

Jimenez-Martin, Sergi "Indexation and Wage Settlement: Evidence from Spanish Manufacturing Firms", Oxford Bulletin of Economics and Statistics, 60(4), 449-484, 1998

Jimenez-Martin, Sergi "Controlling the endogeneity of strike variables in the estimation of wage settlement equations", Journal of Labor Economics, 17(3), 587-606, 1999.

Jordana, J. (1997), "Reconsidering Union membership in Spain, 1977-1994: Halting decline in a context of democratic consolidation", Industrial Relations Journal, vol. 27, pp. 211-224

Kennan, John "Pareto Optimality and the Economics of Strike Duration," Journal of Labor Research, 1 (1980): 77-94.

"The Economics of Strikes", Ch. 19, 1091-1137, in O. Ashenfelter and R. Layard (eds) Handbook of

Labor Economics, vol. 2 Amsterdam: North-Holland. 1986.

and Wilson, Robert "Strategic Bargaining Models and Interpretation of Strike Data," Journal of Applied Econometrics, 4 (1989): s87-s130.

and ___ "Bargaining with Private Information," Journal of Economic Literature, 31 (1993): 45-

104.

Lacroix, Robert "A Microeconometric Analysis of the Effects of Strikes on Wages," Relations Industrielles, 41 (1986): 111-126.

McConnell, Sheena "Strikes, Wages and Private Information," American Economic Review, 79 (1989): 801815.

Morton, Sandford "The Optimality of Strikes in Labor Negotiations," Discussion Paper No 83-7, Murphy Institute for Economics. Tulane Univ, 1983.

van Ours, Jan C. and van de Wijngaert, Rob F. "Holdouts and Wage Negotiations in the Netherlands," Economics Letters, 53 (1996): 83-88.

Reder, Melvin W. and Neumann, George R. "Conflict and Contract: The Case of Strikes," Journal of Political Economy, 88 (1980): 867-886.

Ridell, Craig W. "The Effects of Strikes and Strike Length on Negotiated Wage Settlements," Relations Industrielles, 35 (1980): 115-120.

Siebert, W. Stanley and Addison, John T. "Are Strikes Accidental?," The Economic Journal, 91 (1981): 389-404.

Stengos, Tanos and Swidinsky, Robert "The Wage Effects of a Strike: A Selectivity Bias Approach," Applied Economics, 22 (1990): 375-385.

Vroman, Wayne "Wage Contracts Settlements in U.S. Manufacturing," Review of Economics and Statistics, 66 (1984): 661-665.

Wooldrigde, John M. "Selection Corrections for Panel Data under Conditional Mean Independence Assumptions," Journal of Econometrics, 68 (1995): 115-132. 


\section{Appendix. Data and variables.}

The data used in this paper are from the CBLFS, an annual survey about bargaining in large Spanish firms (with more than 200 employees). Each wave provides information about firm variables (sales, profits), employment and negotiation issues by bargaining unit. Despite the fact that the survey runs from 1978, we only have information for the period 1985-1990. Although it is not a typical panel of data, we are able to use some coded information in order to extract an unbalanced panel of bargaining units. From the original sample, we have excluded firms which did not report information about some key variables such as wages or employment. There are 581 negotiation units in the final sample. The sample is highly unbalanced insofar as there are 335 bargaining units which have two time series observations (see Table A.1). Hence, they do not contribute to the estimation of dynamic models in differences. Thus, the testing of correlated effects becomes of crucial importance. In addition, the table illustrates why lagged strike outcomes are valid instruments for current strike outcomes. The sample probability of observing a strike given that a strike was observed in the former year doubles the unconditional probability of a strike in most years.

Variables. Definition and source.

\section{[Table A.1 here]}

\section{Bargaining unit and firm variables. [Source: CBLFS]}

Wage change: Agreement on wage changes

Difference claim-offer: Work council initial wage change claim - firm initial offer (\%).

retard: 1 if the negotiation starts after the starting date of the agreement.

Employment: Employment in the BU.

Strike indicator: 1 if there is a work stoppage.

S_part: Reported \% of the workforce actively involved in the strike.

Strike duration: Strike hours divided by (employment $\mathrm{S}_{-}$part $* 8$ ) [a proxy of the length in days].

Wage: Wage bill per employee (in logs).

Cost of living allowance signed: Cost of living allowance clause (1 agreed, 0 otherwise).

A single union at the council: 1 if the work council (WC) is formed by a single group.

$\%$ of $\mathrm{CCOO}$ at the council: \% of WC representatives belonging to the nationwide union workers' comissions.

$\%$ of regional at the council: \% WC representatives belonging to any REGIONAL union.

$\%$ of other at the council: \% WC that do not belong to any union.

value added: Gross value added per employee (in logs).

real profits per employee: $100 *$ (Gross real profit per employee).

1 if lagged profits $>0: 1$ if there are positive profits.

$\%$ of sales in the domestic market: Percentage of sales in the domestic market.

Share of $K$ owned by foreigners: Percentage of foreign agents ownership.

Share of K owned by the public sector: Percentage of public sector ownership.

Industry, regional or aggregate variables.

industry average wage change signal: Industry average of the settlements signed in the month preceding the signing (\%). (Ministerio de Trabajo: Estadística de Convenios Colectivos)

Industry average wage: Industry wage level (1 digit SIC) (in logs). (Instituto Nacional de Estadística (INE): Encuesta de Salarios)

Industry conflicting activity: Industry average working days lost by strike per employee. (Ministerio de Trabajo: Boletín de Estadísticas Laborales)

Industry employment level: Employment in the j industry (44). (INE: Encuesta de Población Activa (EPA)).

regional unemployment level: Regional market unemployment ratio (in logs). (EPA)

price expectations: ARIMA price increase forecast at the date of signing the contract.

\section{[Table A.2 here]}




\section{Notes.}

${ }^{1}$ Among the different theories that predict such a relationship, we mention the Union-Political Model of Ashenfelter and Johnson (1969), the Joint Cost Theory of Reder and Neumann (1980) and Kennan (1980) and the one-sided asymmetric information (OSAI) models of Morton (1983) and Hayes (1984). OSAI models provide a rational explanation for the existence of strikes during negotiations. In those models it is suggested that, in the presence of asymmetric information, a strike is used as a mechanism to reveal the firm's level of profitability. For a review of all these theories see Kennan and Wilson (1993).

${ }^{2}$ In Cramton and Tracy (1994), the formation of offers crucially depends on the previous wage. So, some sort of initial can be expected in wage negotiations.

${ }^{3}$ As mentioned before, there is not much theoretical work considering separate wage equations for each strike regime. An interesting exception is Cramton and Tracy (1994, 2003) who stresses that employees could take other action besides strikes, and that these actions may lead to different wage equations.

${ }^{4}$ See Hartog and Theewes (1993) for an excellent cross-National comparative study of labor markets and institutions.

${ }^{5}$ Spanish trade union are mostly publicly financed However, as reported in Jordana (1997) in the second part of the eighties and the beginning of the nineties (precisely, our sample period) there has been an increase in union's affiliation among those in the labor force. The rate of affiliation has increased from 10 percent in 1986 till more than 15 per cent in 1991.

${ }^{6}$ Negotiation at the firm-level proceeds as follows. It starts when the works council makes a wage change claim. The institutional setting is such that the firm must counter offer before a predetermined deadline. If this offer equals the claim, there is an immediate agreement. If not, they alternate offers until an agreement is reached. In the meantime, the council uses a latent strike threat. There are several institutional features which condition this threat during the negotiation. First, it is unusual to call for a strike before both the claim and the offer have been announced. Second, the councils must compulsorily inform the firm in advance of the starting date for the strike. Moreover, they declare the length of the work stoppage or, alternatively, an indefinite threat. Third, the firm cannot hire temporary replacement workers. Finally, workers must compulsorily guarantee a minimum service level in some key industries (such as transportation and utilities sectors).

${ }^{7}$ See Cramton and Tracy (2003) for a comprehensive overview of these models (with the addition of recent developments) and applications.

${ }^{8}$ This possibility has been recently considered by Cramton and Tracy (1994, 2003) who analyze a model with two threats (strike and delay), each of them leading a different wage equation.

${ }^{9}$ See Blanchard \& Katz (1999) for a discussion on wage dynamics.

${ }^{10}$ See Blanchard \& Katz (1999) for a discussion on wage dynamics.

${ }^{11}$ The inverse Mill's ratio or Heckman's (1976) lambda is obtained from a year-by-year model of the probability of observing a conflict in a given negotiation (see Jimenez-Martin, 1995, for details).

${ }^{12}$ Since, first differencing implies that we give up an important share of the sample for estimation, we report a Sargandifference test (Holtz-Eakin, 1988, and Arellano, 1993). This test accounts for the lack of orthogonality between the errors in levels and the set of additional instruments that the level estimation procedure has with respect to the firstdifferenced estimates. The test is distributed as a chi-square distribution with $r$ degrees of freedom, where $r$ is the number of additional orthogonality restrictions implied by the model in levels. [see Holtz-Eakin (1988) or Jiménez-Martín (1998) for a detailed explanation].

${ }^{13}$ Given the small sample size relative to the number of potential overidentifying restrictions, we combine the test of restrictions like $E\left(x_{t-1} u_{t}\right)=0$ for the key variables (lagged wage change and strike outcomes) with weaker restrictions like $E\left(\Sigma x_{t-1} u_{t}\right)=0$ for the rest of the firm variables.

${ }^{14}$ Notice that the effective sample here is smaller than in Jimenez-Martin (1999) because of the consideration of the dynamic nature of the problem.

${ }^{15}$ This is in contrast with what level estimates show for this particular coefficient and suggest that in level estimates the lagged endogenous variable is picking up the unobserved bargaining unit heterogeneity.

${ }^{16}$ The non-strike sample includes those firms which have suffered no strike for at least two consecutive years. However, as Wooldridge (1995) shows, the presence of endogenous selection can be tested by considering any of the relevant samples. We cannot conduct a test for sample selection with the firms in the strike regime because there is an insufficient number of observations.

${ }^{17}$ See Blanchard et al. (1995) for a discussion.

${ }^{18}$ In order to compute the premia we follow Stengos and Swidinsky (1990) and Jiménez-Martin (1998). 
Table 1. Wage change determination and strike outcomes.

\begin{tabular}{|c|c|c|c|c|c|}
\hline & (1) & (2) & (3) & $(4)$ & $(5)$ \\
\hline & $\begin{array}{c}\text { all } \\
\text { levels }{ }^{1} \\
\text { coef. } t \text {-st. }\end{array}$ & $\begin{array}{c}\text { all } \\
\text { differences } \\
\text { coef. } t \text {-st. }\end{array}$ & $\begin{array}{c}\text { strike } \\
\text { levels } \\
\text { coef. } t \text {-st. }\end{array}$ & $\begin{array}{c}\text { non-strike } \\
\text { levels }{ }^{1} \\
\text { coef. } t \text {-st. }\end{array}$ & $\begin{array}{c}\text { non-strike } \\
\text { differences } \\
\text { coef. } t \text {-st. }\end{array}$ \\
\hline Constant & $-0.91(1.53)$ & $-0.75(5.85)$ & $-0.69(0.55)$ & $-0.17(0.24)$ & $-0.97(6.08)$ \\
\hline Lagged wage change $e^{2, *}$ & $0.36(15.6)$ & $-0.03(0.76)$ & $0.36(8.06)$ & $0.38(15.0)$ & $-0.24(4.64)$ \\
\hline difference claim-offer ${ }^{2, * *}$ & $0.03(5.61)$ & $0.03(4.25)$ & $0.04(3.38)$ & $0.01(0.66)$ & $0.04(4.42)$ \\
\hline strike indicator ${ }^{2, *}$ & $0.230(1.96)$ & $0.560(4.78)$ & & - & - \\
\hline strike duration $^{2, *}$ & $-0.012(5.69)$ & $-0.030(5.58)$ & $-0.018(1.96)$ & & \\
\hline Selection term & & - & $-0.39(3.66)$ & $0.03(1.83)$ & $0.046(2.31)$ \\
\hline A single union at the council & $-0.18(2.31)$ & $-0.03(0.25)$ & $-0.22(1.16)$ & $-0.13(1.53)$ & -0.00( \\
\hline$\%$ of $\mathrm{CCOO}$ at the council & $0.17(1.98)$ & $0.18(0.89)$ & $0.51(2.48)$ & $0.17(1.75)$ & $0.27(1.44)$ \\
\hline$\%$ of regional at the council & $0.29(1.57)$ & $-1.72(3.30)$ & $0.38(1.13)$ & $0.28(1.13)$ & $-1.26(2.67)$ \\
\hline \% of other at the council & $-0.42(2.46)$ & $0.11(0.32)$ & $0.72(1.80)$ & $-0.36(1.97)$ & $0.73(1.67)$ \\
\hline 1 if negotiation starts with retard & $0.14(2.64)$ & $0.13(1.77)$ & $-0.33(2.75)$ & $0.14(2.34)$ & $0.16(1.60)$ \\
\hline Cost of living allowance signed ${ }^{3, * *}$ & $-0.10(1.35)$ & $-0.41(4.73)$ & $-0.09(0.47)$ & $-0.05(0.56)$ & $-0.28(1.70)$ \\
\hline lagged employment ${ }^{3, * *}$ & $-0.02(1.01)$ & $-0.86(1.34)$ & $-0.02(0.47)$ & $-0.05(1.93)$ & $-1.98(2.65)$ \\
\hline lagged relative wage ${ }^{3, * *}$ & $0.10(1.53)$ & $-0.98(2.58)$ & $-0.12(0.73)$ & $0.12(1.04)$ & $0.39(0.92)$ \\
\hline Change of the value added ${ }^{2, * *}$ & $0.05(0.39)$ & $0.11(1.02)$ & $0.32(1.22)$ & $0.14(1.04)$ & $-0.45(2.51)$ \\
\hline Real lagged profits per employee $e^{2, * *}$ & $0.08(0.59)$ & $1.21(2.75)$ & $0.75(1.97)$ & 0.06( & $0.94(2.40)$ \\
\hline 1 if lagged profits $>0$ & $0.33(5.16)$ & $0.43(3.80)$ & $0.42(2.45)$ & $0.27(3.44)$ & $0.08(0.62)$ \\
\hline \% sales in the domestic market & $-0.03(0.24)$ & $-0.43(1.63)$ & $-0.05(0.24)$ & $-0.10(0.80)$ & $-0.24(0.67)$ \\
\hline share of K owned by foreigners & $0.08(1.44)$ & $-0.18(0.54)$ & $0.05(0.40)$ & $0.00(0.01)$ & $-0.02(0.06)$ \\
\hline id owned by the public s & $-0.26(3.89)$ & $0.89(2.67)$ & $-0.07(0.43)$ & -0.24( & $0.39(1.20)$ \\
\hline Industry conflicting activity $^{2}$ & $-0.11(3.76)$ & $0.12(6.34)$ & $0.19(3.57)$ & -0.06 & 0.17 \\
\hline Regional unemployment rate & $0.23(2.01)$ & $-0.32(1.49)$ & $-0.64(2.25)$ & -0.04( & $-0.06(0.30)$ \\
\hline Dindustry employment level & $-0.35(2.13)$ & $0.01(0.08)$ & $-0.63(0.82)$ & 0.29 & $0.18(0.91)$ \\
\hline Price expectations & $0.16(3.60)$ & $0.13(2.45)$ & $0.51(6.20)$ & $0.17(3.24)$ & $0.06(0.93)$ \\
\hline Industry average wage inc. signal & $0.50(7.05)$ & $0.41(4.93)$ & $0.05(0.39)$ & $0.46(5.67)$ & $0.38(3.74)$ \\
\hline Samnle/obs & all/1131 & all/521 & strike/162 & no-st./969 & no-st./370 \\
\hline Wald $^{4}(d f)$ & $720.6(26)$ & $1185.2(26)$ & $821.0(26)$ & $596.6(26)$ & $911.3(25)$ \\
\hline $\operatorname{Sargan}^{5}(d f)$ & $115.9(101)$ & $79.1(74)$ & $38.8(37)$ & $84.3(80)$ & $68.8(60)$ \\
\hline Fosc $^{6}(o b s)$ & -0.86 & -4.03 & - & -0.32 & -2.11 \\
\hline $\operatorname{Sosc}^{6}(o b s)$ & 1.84 & 0.76 & - & 1.10 & 0.05 \\
\hline Exogeneity of strikes outcomes $^{7}(d f)$ & -- & $33.1(2)$ & - & & \\
\hline Effects test $^{8}(d f)$ & -- & $47.63(27)$ & - & - & $22.80(12)$ \\
\hline Wald column (3) vs (4) & & & - & $49.32(22)$ & - \\
\hline id with omitted dummies & & & - & $192.56(36)$ & - \\
\hline Wald column (2) vs (5) & & & - & - & $41.11(22)$ \\
\hline id with omitted dummies & & & & - & $94.43(28)$ \\
\hline
\end{tabular}

notes:

In levels equations, all the variables are in levels. Likewise, all the first differences equations use differenced data.

1.All the columns consider a full set of year, quarterly and industry dummies (the latter only in level models).

2.Lags of these variables have been used as GMM instruments (-1 and earlier lags in the level models and -2 and earlier in the rest).

3.Instrumented by using their lagged value (levels) or their lagged difference (first differences).

4.Wald test of the null that the vector of coefficients (excluding time and industry dummies) is zero.

5.Test of the validity of the set of instruments. Under the null of adequacy, the test is distributed as $\chi^{2}(r)$, where $r$ is the number of overidentifying restrictions.

6.Test of the absence of first (second) order serial correlation in the error term (Arellano and Bond, 1991).

7.Hausman test (Griliches and Hausman, 1986) comparing estimates obtained under the null of exogeneity and the alternative of predeterminedness.

8.Sargan difference test (Arellano, 1993), under the null hypothesis that both the level and differenced models provide consistent estimates it is distributed as a $\chi_{r}^{2}$, where $\mathrm{r}$ is the number of additional overidentifying restrictions implied by the levels model. For the set of variables marked with $*$ we have tested overidentifying restrictions like $E\left(x_{i t-1} u_{t}\right)=0$ and for those marked with $* *$ we have tested $E\left(\Sigma x_{i t-l} u_{t}\right)=0$, being $u_{t}$ a levels error.

9.Wald test of the hypothesis that the coefficients, excluding the strike variables and the selection term, of columns $i$ and $j$ are equal. In the first row we test all the variables whose coefficients are reported in the table, whereas in the second row we also consider the variables omitted (time and industry dummies). 
Table 2. A summary on results about strike variables and wage decline in a dynamic context.

\begin{tabular}{|c|c|c|c|c|c|c|c|c|c|}
\hline \multirow[b]{2}{*}{ sample } & \multirow[b]{2}{*}{ table } & \multicolumn{2}{|c|}{ strike coefficients } & \multicolumn{4}{|c|}{$\%$ effect wage changes ${ }^{3}$} & \multicolumn{2}{|c|}{ \%effect wage levels ${ }^{4}$} \\
\hline & & $s^{1}$ & $d^{2}$ & $D=1$ & $d=5$ & $d=15$ & $d=30$ & $d=30$ & $d=100$ \\
\hline all & $1(1)$ & 0.232 & -0.012 & 3.20 & 2.50 & 0.76 & -1.86 & -0.11 & -0.91 \\
\hline all & $1(2)$ & 0.560 & -0.030 & 7.71 & 5.97 & 1.60 & -4.95 & -0.32 & -2.28 \\
\hline strike & $1(3)$ & - & -0.018 & -0.26 & -1.30 & -3.90 & -7.80 & -0.51 & -1.68 \\
\hline
\end{tabular}

notes:

1.Strike indicator.

2. Length of a strike (in days).

$3.100 *\left(\delta_{l} s+\delta_{2} d\right) / \overline{\mathrm{W}} ; \overline{\mathrm{W}}=6.87$

$4.100 *\left[\left(100+\overline{\mathrm{W}}+\delta_{1} s+\delta_{2} d\right) /(100+\overline{\mathrm{w}})-1\right]$

Table 3. Implicit wage change differential.

\begin{tabular}{|c|c|c|c|}
\hline & corrected $^{1}$ & non-corrected ${ }^{2}$ & observed $^{3}$ \\
\hline ALL (strike length=4.93) & 0.329 & 0.355 & 0.252 \\
\hline Energy & -0.051 & -0.016 & 0.202 \\
\hline Minerals and Chemical & 0.409 & 0.416 & 0.353 \\
\hline Metal Processing & 0.245 & 0.353 & 0.255 \\
\hline Other Manufacturing & 0.203 & 0.211 & 0.107 \\
\hline Building & 0.378 & 0.497 & 0.146 \\
\hline Retail Services & 0.978 & 0.898 & 0.658 \\
\hline Transportation & 0.565 & 0.640 & 0.284 \\
\hline Others Services & 0.456 & 0.394 & 0.471 \\
\hline$A L L ; d=15$ & 0.149 & 0.174 & - \\
\hline$A L L ; d=30$ & -0.119 & -0.095 & - \\
\hline$A L L ; d=100$ & -1.370 & -1.350 & - \\
\hline
\end{tabular}

1.The corrected differential can be expressed as: $C D=(1 / M) \sum_{i=1}^{N} \Sigma_{t i o}^{T_{i}}\left[E\left\{\Delta \widehat{w}_{i t}^{I} / s_{i t}=1\right\}-E\left\{\Delta \widehat{w}_{i t}^{0} / s_{i t}=0\right\}\right]$ where $M$ is the number of observations, $\Delta \widehat{w}_{i t}^{I}$ is the prediction of the strike model (Table 3(1)) and $\Delta \bar{w}_{i t}^{0}$ is the prediction of the non-strike model (Table 3(2)), both considering the selection terms.

2. The uncorrected differential is defined as: $U D=C D-\left\{\sigma_{w 0} \bar{\lambda}_{w 1}-\sigma_{w 0} \hat{\lambda}_{w 0}\right\}$.

3. Difference of the observed strike and non-strike wage changes (controlled for year and sector) 
Table A.1. Structure of the sample and some descriptive evidence

\begin{tabular}{|c|c|c|c|c|c|c|c|}
\hline \# of annual observations & & & 2 & 3 & 4 & 5 & 6 \\
\hline $\begin{array}{l}\text { number of bargaining units } \\
\text { strike incidence \% }\end{array}$ & & & $\begin{array}{l}335 \\
13.4\end{array}$ & $\begin{array}{l}127 \\
14.8\end{array}$ & $\begin{array}{c}78 \\
16.6\end{array}$ & $\begin{array}{c}42 \\
13.8\end{array}$ & $\begin{array}{c}28 \\
14.2\end{array}$ \\
\hline sectors ${ }^{I}$ & 2 & 3 & 4 & 5 & 6 & 7 & 8 \\
\hline $\begin{array}{l}\text { observations } \\
\text { strike incidence\% }\end{array}$ & $\begin{array}{l}294 \\
13.3\end{array}$ & $\begin{array}{l}402 \\
24.4\end{array}$ & $\begin{array}{l}418 \\
12.2\end{array}$ & $\begin{array}{c}39 \\
28.2\end{array}$ & $\begin{array}{l}82 \\
8.5\end{array}$ & $\begin{array}{l}115 \\
20.9\end{array}$ & $\begin{array}{l}268 \\
4.9\end{array}$ \\
\hline years & all & 85 & 86 & 87 & 88 & 89 & 90 \\
\hline $\begin{array}{l}\text { observations } \\
\text { conditional strike duration(days) } \\
\text { strike incidence \% } \\
\text { Conditional strike incidence \%: }\end{array}$ & $\begin{array}{l}1712 \\
5.11 \\
14.5\end{array}$ & $\begin{array}{l}132 \\
6.93 \\
18.7\end{array}$ & $\begin{array}{l}247 \\
5.51 \\
10.1\end{array}$ & $\begin{array}{l}316 \\
5.30 \\
19.6\end{array}$ & $\begin{array}{l}327 \\
4.74 \\
13.5\end{array}$ & $\begin{array}{l}411 \\
5.06 \\
15.2\end{array}$ & $\begin{array}{l}308 \\
3.23 \\
11.0\end{array}$ \\
\hline$\overline{\text { strike in } t-1}$ & 30.1 & $48.3^{3}$ & 37.5 & 34.7 & 22.2 & 37.0 & 16.1 \\
\hline strike in $t-1$ and $t-2$ & 37.0 & & 41.7 & 30.0 & 20.0 & 54.5 & 31.3 \\
\hline strike in $t-1$ or $t-2$ or $t-3$ & 24.6 & & & 41.7 & 23.7 & 24.6 & 19.1 \\
\hline strike in $t-1$ and no-strike in $t-2$ & 22.7 & & 41.7 & 37.5 & 23.4 & 28.0 & 10.0 \\
\hline no strike in $t-1$ and strike in $t-2$ & 20.5 & & 20.0 & 36.8 & 41.7 & 13.2 & 12.1 \\
\hline no strike in $t-1$ & 11.7 & $\overline{12.4}^{3}$ & 5.3 & 18.5 & 11.1 & 11.2 & 9.9 \\
\hline no strike in $t-1$ and $t-2$ & 10.7 & & 5.1 & 16.3 & 9.5 & 11.0 & 9.6 \\
\hline no strike in $t-1, t-2$ and $t-3$ & 12.1 & & & 21.9 & 14.6 & 10.6 & 5.8 \\
\hline
\end{tabular}

notes:

1.Sector' names are reported in Table A.2

2.To exclude the possibility that the sample selection criteria influence the conditional strike incidence we performed the same analysis using both the original sample and a balanced subsample. They fully confirm the above patterns.

3.Despite the sample period starts in 1985 , we dispose of data from the strike variables for 1984. 
Table A.2. Variables. Descriptive statistics.

\begin{tabular}{|c|c|c|c|c|}
\hline & \multicolumn{2}{|c|}{$\begin{array}{l}\text { non-strike } \\
1479 \_o b s .\end{array}$} & \multicolumn{2}{|c|}{$\begin{array}{c}\text { strike } \\
262 \_o b s .\end{array}$} \\
\hline & Mean & st.dev. & mean & st.dev. \\
\hline \multicolumn{5}{|l|}{ Wage variables } \\
\hline$\overline{\text { Wage change }}$ & 6.8573 & 1.3814 & 6.9401 & 1.3416 \\
\hline $\begin{array}{l}\text { difference claim-offer } \\
\text { Strike variables }\end{array}$ & 4.2377 & 4.5680 & 5.9298 & 6.4335 \\
\hline$\overline{\text { strike duration }}$ & 0.0000 & 0.0000 & 4.9318 & 11.993 \\
\hline lagged strike duration & 0.2232 & 1.7017 & 0.2823 & 0.9110 \\
\hline $\begin{array}{l}\text { selection term } \\
\text { Bargaining unit variables }\end{array}$ & -2.7886 & 1.7123 & 0.8163 & 0.6010 \\
\hline$\overline{\text { A single union at the council }}$ & 0.1244 & 0.3301 & 0.0496 & 0.2175 \\
\hline$\%$ of CCOO at the council & 0.3353 & 0.2651 & 0.4126 & 0.2375 \\
\hline$\%$ of regional at the council & 0.0517 & 0.1437 & 0.0665 & 0.1524 \\
\hline$\%$ of other at the council & 0.0546 & 0.1422 & 0.0637 & 0.1298 \\
\hline 1 if the negotiations start with retard & 0.6700 & 0.4703 & 0.7519 & 0.4327 \\
\hline Cost of living allowance signed & 0.7484 & 0.4340 & 0.7709 & 0.4210 \\
\hline lagged employment & 6.2979 & 1.0154 & 6.8977 & 1.3417 \\
\hline $\begin{array}{l}\text { lagged relative wage } \\
\text { Firm variables }\end{array}$ & 3.3986 & 0.3180 & 3.3229 & 0.2580 \\
\hline Change of the value added & 0.0825 & 0.3005 & 0.1143 & 0.3077 \\
\hline Real lagged profits per employee & 0.1032 & 0.1812 & 0.0539 & 0.1568 \\
\hline 1 if lagged profits $>0$ & 0.8302 & 0.3755 & 0.7022 & 0.4581 \\
\hline$\%$ of sales in the domestic market & 0.8742 & 0.2016 & 0.8171 & 0.2349 \\
\hline share of $K$ owned by foreigners & 0.2357 & 0.3846 & 0.2788 & 0.4058 \\
\hline $\begin{array}{l}\text { id owned by the public sector } \\
\text { Industry and aggregate variables }\end{array}$ & 0.1621 & 0.3479 & 0.2653 & 0.4270 \\
\hline$\overline{\text { Industry conflicting activity }}$ & 0.3730 & 0.8307 & 0.6936 & 1.2534 \\
\hline regional unemployment rate & -1.6354 & 0.2028 & -1.6319 & 0.1854 \\
\hline Change in industry employment level & 0.0340 & 0.1163 & 0.0142 & 0.0753 \\
\hline Price expectations & 5.3862 & 1.9856 & 5.4878 & 1.8254 \\
\hline $\begin{array}{l}\text { Industry average wage change signal } \\
\text { Quarterly and Industry dummies }\end{array}$ & 7.0847 & 0.8954 & 6.9815 & 0.8524 \\
\hline Spring & 0.5037 & 0.5001 & 0.5572 & 0.4976 \\
\hline Summer & 0.0885 & 0.2842 & 0.1946 & 0.3966 \\
\hline Fall & 0.0439 & 0.2050 & 0.0305 & 0.1723 \\
\hline 1. Energy & 0.0703 & 0.2557 & 0.0725 & 0.2598 \\
\hline 2. Minerals & 0.1724 & 0.3778 & 0.1488 & 0.3566 \\
\hline 3. Metal_Processing & 0.2055 & 0.4042 & 0.3740 & 0.4848 \\
\hline 4. Other_Manufacturing & 0.2481 & 0.4320 & 0.1946 & 0.3966 \\
\hline 5. Building & 0.0189 & 0.1363 & 0.0419 & 0.2009 \\
\hline 6. Retail Services & 0.0507 & 0.2194 & 0.0267 & 0.1615 \\
\hline 7. Transportation & 0.0615 & 0.2403 & 0.0916 & 0.2890 \\
\hline 8. Other_Services & 0.1724 & 0.3778 & 0.0496 & 0.2175 \\
\hline
\end{tabular}

